\title{
KREDIT MURABAHAH DALAM KITAB HADIS KUTUB AL-TIS'AH (ANALISIS JUAL BELI ANGSURAN/TANGGUH DALAM HUKUM SYARIAH)
}

\author{
Hadi Aksi \\ Seokolah Tinggi Agama Islam (STAI) al-Azhar Pekanbaru Riau \\ Jl. K.H. Ahmad Dahlan No. 96, Kampung Melayu, Sukajadi, Kp. Melayu, Sukajadi, Kota Pekanbaru, Riau \\ e-mail: alhadijurnal@gmail.com
}

\begin{abstract}
Abstrak: Transaksi jual beli dengan memakai sistem kredit (cicilan) merupakan salah satu transaksi yang biasa dilakukan masyarakat Indonesia dewasa ini, transaksi ini sangat diminati masyarakat, karena pembeli bisa langsung memakai produk yang diimpikannya, tanpa harusmembayar kontan. Transaksi ini tentunya sudah sangat merakyat di Indonesia, tapi masih banyak dari mereka yang masih bertanya-tanya, bagaimana hukum sistem jual beli tersebut menurut syari'at Islam, apakah Nabi Muhammad saw pernah melakukannya. Metode yang digunakan adalah library research terhadap kutub tis'ah dan dianalisis secara deskriptif anlytic. Hasil penelitian menemukan dalam Mausu'ah Bukhari ada dua hadis, yaitu Kitab : Jual beli, Bab: Nabi saw membeli dengan cara tempo, No. Hadis: 1926. Kitab : siasat mengelak, Bab: Hibah dan Syuf'ah, No. Hadist: 6462. Mausu'ah Tirmizi ada satu hadis, yaitu Kitab : Jual beli, Bab: Larangan dua akad dalam satu jual-beli, No. Hadist: 1152. Mausu'ah Nasa'i ada empat hadis, yaitu Kitab : Iman dan nadzar, Bab: Perbedaan lafadh yang matsur tentang Muzaro'ah, No. Hadist: 3875. Kitab: Jual-beli, Bab: Membeli perak dengan emas atau membeli emas dengan perak, No. Hadist: 4504. Kitab: Jual-beli, Bab: Menjual hewan dengan hewan yang dibayarkan secara tangguh, No. Hadist: 4541. Kitab: Jual-beli, Bab: Jual beli dengan ahli kitab, No. Hadist: 4571. Mausu'ah Ahmad ada tiga hadis, yaitu Kitab: Musnad sahabat yang banyak meriwayatkan hadits, Bab: Musnad Abdullah bin Mas'ud Radliyallahu ta'ala 'anhu, No. Hadist: 3595. Kitab: Musnad penduduk Madinah, Bab: Hadits Hisyam bin 'Amir Al Anshari Radliyallahu ta'ala 'anhu, No. Hadist: 15663. Kitab: Musnad penduduk Madinah, Bab: Hadits Hisyam bin 'Amir Al Anshari Radliyallahu ta'ala 'anhu, No. Hadist: 15675. Mausu'ah Malik ada dua hadis, yaitu Kitab: Jual-beli, Bab: Dari kakeknya, Malik bin Abu Amir, bahwa Utsman bin Affan. No. Hadist: 1148. Kitab: Jual-beli, Bab: Utang dan pengalihan utang, No. Hadist: 1182.
\end{abstract}

Kata kunci: Hadis-Hadis, Kredit, Murabahah, Kutub Al-Tis'ah.

Abstract: Buying and selling transactions using the credit system (installment) is one of the
transactions commonly done by Indonesian people today, this transaction is very popular with the
public, because buyers can directly use the product they dream of, without having to pay cash. This
transaction certainly has been very popular in Indonesia, but there are still many of them who are
still wondering, how is the law of the sale and purchase system according to Islamic law, whether
the Prophet Muhammad ever did it. The Method for this research is library research with
descriptiveanalytic study. The results of the study found in Mausu'ah Bukhari there were two
hadiths, namely the Book: Buying and selling, Chapter: The Prophet (peace be upon him) bought it
by means of tempo, No. Hadith: 1926. Book: evasive tactics, Chapter: Hibah and Syuf ah, No.
Hadith: 6462. Mausu'ah Tirmizi there is one hadith, namely the Book: Buying and selling, Chapter:
Prohibition of two contracts in one sale, No. Hadith: 1152. Mausu'ah Nasa'i there are four
traditions, namely the Book: Faith and nadzar, Chapter: The most different difference "tsur about
Muzaro'ah, No. Hadith: 3875 . Book: Buying and selling, Chapter: Buying silver with gold or buying
gold with silver, No. Hadith: 4504. Book: Buying and selling, Chapter: Selling animals with animals
that are paid fairly, No. Hadith: 4541. Kitab: Buying and selling, Chapter: Buying and selling with 
book experts, No. Hadith: 4571. Mausu'ah Ahmad there are three traditions, namely the Book: Musnad companions who narrated the hadith, Chapter: Musnad Abdullah bin Mas'ud Radliyallahu ta'ala 'anhu, No. Hadith: 3595. Book: Musnad resident Medina, Chapter: Hadith Hisham bin 'Amir Al Anshari Radliyallahu ta'ala' anhu, No. Hadith: 15663. Book: Musnad inhabitants of Medina, Chapter: Hadith Hisham ibn 'Amir Al Anshari Radliyallahu ta'ala' anhu, No. Hadith: 15675. Mausu'ah Malik there are two traditions, namely the Book: Buying and selling, Chapter: From his grandfather, Malik bin Abu Amir, that Uthman ibn Affan No. Hadith: 1148. Book: Buying and selling, Chapter: Debt and debt transfer, No. Hadith: 1182.

Keywords: Hadiths, Credit, Murabahah, Kutub Al-Tis'ah.

\section{Pendahuluan}

Era modern dan serba canggih ini perkembangan sistem ekonomi sudah sangat pesat. Beragam sistem ditawarkan oleh para pembisnis untuk bersaing menggaet hati para pelanggan. Seorang ekonomi muslim yang tidak hanya berorientasi pada keuntungan dunia saja, sudah semestinya harus cerdik, juga senantiasa menganalisa fenomena perkembangan kegiatan bisnis yang ada, agar mengetahui bagaimana pandangan

syariat terhadap suatau transaksi bisnis. Dengan demikian tidak mudah terjerumus ke dalam larangan-Nya (riba). ${ }^{1}$

Kegiatan ekonomi bisnis yang sangat di gemari kebanyakan masyarakat adalah jual beli. Baik secara tunai atau secara angsuran. Salah satu transaksi yang cepat mendapatkan barang dan keuntungan adalah jual beli kredit. Jual beli sistem kredit masuk di segala bentuk sistem bisnis. Sistem ini mulai diminati banyak kalangan, karena rata-rata manusia itu kalangan menengah ke bawah, yang mana kadang-kadang mereka terdesak untuk membeli barang tertentu yang tidak

\footnotetext{
${ }^{1}$ Muslim, Tinjanan Syariat Terbadap Jual-Beli Kredit, lihat di wibesite online https:// muslim.or.id/20961-tinjauan-syariat-terhadapjual-beli-kredit.html.diakses tanggal 20 september 2018.
}

bisa dia beli dengan kontan, maka kredit adalah pilihan yang mungkin dirasa tepat. ${ }^{2}$

Transaksi jual beli dengan memakai sistem kredit (cicilan) merupakan salah satu transaksi yang biasa dilakukan masyarakat Indonesia dewasa ini, transaksi ini sangat diminati masyarakat, karena pembeli bisa langsung memakai produk yang diimpikannya, tanpa harusmembayar kontan. ${ }^{3}$ Biasanya, transaksi ini sangat diminati oleh masyarakat yang mempunyai penghasilan tetap dan terjamin, seperti pegawai negeri, tentara, dan karyawan. Tetapi tidak jarang juga diminati oleh pengusaha kecil seperti tukang ojek, dengan uang satu juta di tangan, dia bisa langsung ngojek, uang itu dipakai untuk membayar uang muka (DP ; Down Payment), yang kemudian, pembayaran selanjutnya dicicil dari hasil keuntungan usahanya. Transaksi ini tentunya sudah sangat merakyat di Indonesia, tapi masih banyak dari mereka yang masih

\footnotetext{
${ }^{2}$ Abu Zuhry dan Ahmad Sabiq, Hukum Jual Beli Kredit, lihat di wibesite online dalam https:/ /abuzuhriy.wordpress.com/2010/10/03/hukumjual-beli-kredit/.diakses tanggal 21 september 2018.

${ }^{3}$ Miftah, Transaksi jual Beli Kredit (Cicilan) Dalam Syariat Islam, lihat wibesite online di http://mejamiftah.blogspot.com/2010/12/transaksi-jual-beli-kreditcicilan.html.diakses tanggal 20 september 2018.
} 
bertanya-tanya, bagaimana hukum sistem jual beli tersebut menurut syari'at Islam, apakah Nabi Muhammad saw pernah melakukannya. ${ }^{4}$ Maka dalam tulisan penelitian ini akan membahas teks nash hadis Nabi saw dalam masalah kredit murabahah dalam kitab hadis kutub al-Tisa'ah.

\section{Kerangka Teori}

\section{Konsep Kredit}

Defenisi kredit dalam normatif hukum, terdapat pada Undang-Undang Perbankan No. 10 Tahun 1998 adalah penyediaan uang atau tagihan yang dapat dipersamakan dengan itu, berdasarkan persetujuan atau kesepakatan pinjam meminjam antara bank dengan pihak lain yang mewajibkan pihak peminjam melunasi utangnya setelah jangka waktu tertentu dengan pemberian bunga. ${ }^{5}$ Menurut Kasmir pembiayaan adalah sama sengan kredit hanya saja dengan imbalan atau bagi hasil. ${ }^{6}$ Menurut Khairul Umam pembiayaan adalah tagihan dengan imbalan Ujrah, tanpa imbalan atau bagi hasil memakai akad-akad syariah. ${ }^{7}$ Menurut Danupranata pembiayaan adalah pemberian fasilitas penyediaan dana Syari'at Islam.

${ }^{4}$ Miftah, Transaksi jual Beli Kredit (Cicilan) Dalam

${ }^{5} U U$ No 10 Th 1998 tentang Perbankan. Lihat Malayu Hasibuan, Dasar-Dasar Perbankan (Jakarta: PT Bumi Aksara, 2008), hlm. 87; lihat juga Nurhadi, Hilah Syariah Kredit Bank Konvesional (Maqashid Jual Beli Kredit (Lain Kontrak Lain Akad)), (Jurnal Hukum Islam, Vol XVII No. 2 Desember 2017), hlm. 115

'Kasmir, Analisis Laporan Kenangan (Jakarta: Rajawali Pers, 2013), cet. VI, ed. 1, hlm. 113. Kasmir, Bank dan Lembaga Keuangan Lainnya (Jakarta: Rajawali Pers, 2012), hlm. 127

${ }^{7}$ Khaerul Umam, Manajemen Perbankan Syariah (Bandung: CV. Pustaka Setia, 2013), hlm. 205 untuk memenuhi kebutuhan pihak-pihak yang tergolong mengalami kekurangan dana, pembiayaan produktif adalah jenis pembiayaan untuk peningkatan usaha, baik usaha produksi, perdagangan maupun investasi,sedangkan pembiayaan konsumtif adalah digunakan untuk memenuhi kebutuhan konsumsi, yang akan habis digunakan saat dipakai untuk memenuhi kebutuhan. ${ }^{8}$

Perbankan dalam memberikan kredit setidaknya memiliki unsure sebagai berikut: 1). Kepercayaan. 2). Kesepakatan. 3). Jangka Waktu. 4). Resiko. 5). Balas Jasa. ${ }^{9}$ 6). Degree of Risk. ${ }^{10}$ Tujuan kredit adalah: 1). Mencari Keuntungan. 2). Membantu Usaha Nasabah (perusahaan). 3). Membantu Pemerintah. ${ }^{11} 4$ ). Melaksanakan kegiatan operasional bank. 5). Memenuhi permintaan kredit dari masyarakat. 6). Memperlancar lalu lintas pembayaran. 7). Meningkatkan pendapatan dan kesejahteraan masyarakat. ${ }^{12}$ 8). Turut menyukseskan program pemerintah di bidang ekonomi dan pembangunan. ${ }^{13}$

\footnotetext{
8Danupranata, Gita, Manajemen Perbankan Syariah (Jakarta : Salemba empat, 2013), hlm. 103

${ }^{9}$ Kasmir, Bank dan Lembaga Keuangan Lainnya (Jakarta: Rajawali Pers, 2012), hlm.114-115; Nurhadi, Hilah Syariah Kredit, hlm. 116

${ }^{10}$ Simorangkir, Pengantar Lembaga Keuangan Bank dan Non Bank (Jakarta: Ghalia Indonesia, 2001), hlm. 101-102

${ }^{11}$ Kasmir, Bank dan Lembaga Kenangan Lainnya (Jakarta: Rajawali Pers, 2012), hlm. 116

${ }^{12}$ Malayu Hasibuan, Dasar-Dasar Perbankan (Jakarta: PT. Bumi Aksara, 2008) dan (Jakarta: PT. Grafindo, 2008), hlm. 88

${ }^{13}$ Simorangkir, Pengantar Lembaga Keuangan Bank dan Non Bank (Jakarta: Ghalia Indonesia, 2001), hlm. 102; Nurhadi, Hilab Syariah Kredit, hlm. 117
} 
Secara umum fungsi kredit adalah: 1). Untuk Meningkatkan Daya Guna Uang. 2). Untuk Meningkatkan Peredaran Dan Lalu Lintas Uang. 3). Untuk Meningkatkan Daya Guna Barang. 4). Meningkatkan Peredaran Barang. 5). Sebagai Alat Stabilitas Ekonomi. 6). Untuk Meningkatkan Kegairahan Berusaha. 7). Untuk Meningkatkan Pemerataan Pendapatan. 8). Untuk Meningkatkan Hubungan Internasional(L/C, CGI, dan lain-lain). ${ }^{14}$ 9). Menjadi motivator dan dinamisator peningkatan kegiatan perdagangan dan perekonomian. 10). Memperbesar modal kerja perusahaan. 11). Meningkatkan income per capita (IRC) masyarakat. 12). Mengubah cara berpikir/bertindak masyarakat untuk lebih ekonomis. ${ }^{15}$

\section{Konsep Murabahah}

Ada beberapa tipe penerapan murabahah dalam praktik kredit syariah yang kesemuanya dapat dibagi menjadi tiga kategori besar, yaitu: ${ }^{16}$

1) Tipe penerapan murabahah adalah tipe konsisten terhadap fiqih muamalah. Dalam tipe ini bank membeli dahulu barang yang akan dibeli oleh nasabah setelah ada perjanjian sebelumnya. Setelah barang dibeli atas nama bank kemudian dijual

\footnotetext{
${ }^{14}$ Kasmir, Bank dan Lembaga, hlm.117-119.

Lihat Budi Untung, Kredit Perbankan di Indonesia (Yogyakarta: Andi, 2004), hlm. 4-5

${ }^{15}$ Malayu Hasibuan, Dasar-dasar Perbankan, hlm. 88-89

${ }^{16}$ Ah. Azharuddin Lathif, Konsep dan Aplikasi Akad Murabahah Pada Perbankan Syariah di Indosesia..., (Buku Tidak Diterbitkan, Jakarta, t.th), hlm. 13
}

ke nasabah dengan harga perolehan ditambah margin keuntungan sesuai kesepakatan. Pembelian dapat dilakukan secara tunai (cash), atau tangguh baik berupa angsuran atau sekaligus pada waktu tertentu. Pada umumnya nasabah membayar secara tangguh. ${ }^{17}$

2) Tipe mirip dengan tipe yang pertama, tapi perpindahan kepemilikan langsung dari supplier kepada nasabah, sedangkan pembayaran dilakukan bank langsung kepada penjual pertama/supplier. Nasabah selaku pembeli akhir menerima barang setelah sebelumnya melakukan perjanjian murabahah dengan bank. Pembelian dapat dilakukan secara tunai (cash), atau tangguh baik berupa angsuran atau sekaligus pada waktu tertentu. ${ }^{18}$ Pada umumnya nasabah membayar secara tangguh. Transaksi ini lebih dekat dengan murabahah yang asli, tapi rawan dari masalah legal. ${ }^{19}$ Dalam beberapa kasus ditemukan adanya klaim nasabah bahwa mereka tidak berhutang

${ }^{17}$ Azzifathur Roifah Nim. 3223113021 , Implementasi Pembiayaan Murabahah Bil Wakalab Sebagai Upaya Untuk. Meningkatkan Ekonomi, (Peternak Sapi Pada Lks Asri Cabang Sendang Jurusan Perbankan Syariah Fakultas Ekonomi Dan Bisnis Islam Institut Agama Islam Negeri (IAIN) Tulungagung 2015), hlm. 28

18 Azzifathur Roifah, Implementasi Pembiayaan Murabahah, hlm. 28-29

${ }^{19}$ Nurhadi, Analisis Hukum Perikatan Klausul Akad Pembiayaan Murabahah Bil Wakalah Nomor.090/Mrbb/Pkb/V/2016 Bank Rakyat Indonesia Syariah (Tesis: Program Magister (S2) Program Pascasarjana Universitas Islam Riau Pekanbaru, 2016), hlm. 21 
kepada bank, tapi kepada pihak ketiga yang mengirimkan barang. Meskipun nasabah telah menandatangani perjanjian murabahah dengan bank, perjanjian ini kurang memiliki kekuatan hukum karena tidak ada tanda bukti bahwa nasabah menerima uang dari bank sebagai bukti pinjaman/hutang. Untuk mengindari kejadian seperti itu maka ketika bank syariah dan nasabah telah menyetujui untuk melakukan transaksi murabahah maka bank akan mentransfer pembayaran barang ke rekening nasabah (numpang lewat) kemudian didebet dengan persetujuan nasabah untuk ditransfer ke rekening supplier. Dengan cara seperti ini maka ada bukti bahwa dana pernah ditransfer ke rekening nasabah. Namun demikian, dari perspektif syariah model murabahah seperti ini tetap saja berpeluang melanggar ketentuan syariah jika pihak bank sebagai pembeli pertama tidak pernah menerima barang (qabdh) atas namanya tetapi langsung atas nama nasabah. Karena dalam prinsip syariah akad jual beli murabahah harus dilakukan setelah barang, secara prinsip, menjadi milik bank. ${ }^{20}$

3) Tipe yang paling banyak dipraktekkan oleh bank syariah. Bank melakukan perjajian murabahah dengan nasabah, dan pada saat yang sama mewakilkan Murabahah, hlm. 29 (akad wakalah) kepada nasabah untuk membeli sendiri barang yang akan dibelinya. Dana lalu dikredit ke rekening nasabah dan nasabah menandatangi tanda terima uang. Tanda terima uang ini menjadi dasar bagi bank untuk menghindari klaim bahwa nasabah tidak berhutang kepada bank karena tidak menerima uang sebagai sarana pinjaman. Tipe ketiga ini bisa menyalahi ketentuan syariah jika bank mewakilkan kepada nasabah untuk membeli barang dari pihak ketiga, sementara akad jual beli murabahah telah dilakukan sebelum barang, secara prinsip, menjadi milik bank. $^{21}$

Melalui Peraturan Bank Indonesia (PBI) nomor 9/19/PBI/2007 serta Surat Edaran BI No. 10/14/DPbS tanggal 17 Maret 2008 yang menghapus keberlakuan PBI Nomor 7/46/PBI/2005 tentang Akad penghimpunan dan Penyaluran dana Bank Yang Melaksanakan Kegiatan Usaha Berdasarkan Prinsip Syariah, pelaksanaan pembiayaan murabahah semakin menempatkan bank syariah semata-mata lembaga intermediasi yang bertindak sebagai penyedia dana bukan pelaku jual beli murabahah. ${ }^{22} \mathrm{Hal}$ ini ditegaskan dalam teks Surat Edaran BI No. 10/14/DPbS pada point III bahwa "Bank bertindak sebagai

\footnotetext{
${ }^{21}$ Ah. Azharuddin Lathif, Konsep dan Aplikasi Akad Murabahah Pada Perbankan Syariah di Indosesia..., (Buku Tidak Diterbitkan, Jakarta, t.th), hlm. 15

22Undang-Undang Nomor 21 Tahun 2008 tentang Perbankan Syariah Pasal 19 angka 1 huruf d.; Nurhadi, Analisis Hukum Perikatan, hlm. 23
} 
pihak penyedia dana dalam rangka membelikan barang terkait dengan kegiatan transaksi murabahah dengan nasabah sebagai pihak pembeli barang". Di lihat dari teks surat edaran ini, jelas ada upaya Bank Indonesia untuk menegaskan bahwa transaksi perbankan syariah yang didasarkan pada prinsip jual beli murabahah tetap merupakan pembiayaan sebagaimana transaksi lainnya yang menggunakan akad mudharabah, musyarakah, salam, istishna, ijarah, dan ijarah muntahiya bit tamlik. ${ }^{23}$

Murabahah bil Wakalah berdasarkan

Fatwa Dewan Syariah Nasional No: 04/DSN-MUI/IV/2000, yaitu jika bank mewakilkan kepada nasabah untuk membeli barang dari pihak ketiga, akad jual beli murabahah harus dilakukan setelah barang, secara prinsip, menjadi milik bank. Selalu terjadi akad wakalah dulu sebelum akad murabahah karena akad wakalah akan berakhir pada saat nasabah menyerahkan barang yang dibeli pada bank dan mempercepat proses pencairan dan memudahkan nasabah, sehingga setelah barang diterima oleh bank maka terjadilah akad murabahah. ${ }^{24}$ Sedangkan menurut Undang-Undang Nomor 21 Tahun 2008 tentang Perbankan Syariah Pasal 19 angka 1

${ }^{23}$ Azzifathur Roifah, Implementasi Pembiayaan Murabahah Bil Wakalab Sebagai Upaya Untuk Meningkatkan Ekonomi, Peternak Sapi Pada Lks Asri Cabang Sendang Skripsi Jurusan Perbankan Syariah Fakultas Ekonomi Dan Bisnis Islam Institut Agama Islam Negeri (IAIN) (Tulungagung, 2015), hlm. 32

${ }^{24}$ Kurneawati, Analisis Perlakuan Akuntansi Piutang Murabahab Pada PT. Bank BRI Syariah KCI Gubeng Surabaya, (Penelitian Tidak Diterbitkan, Surabaya, 201), hlm. 5 huruf o, bahwa bank boleh melakukan fungsi sebagai Wali Amanat berdasarkan Akad wakalah. ${ }^{25}$

Landasan hukum syariah tentang wakalah al-Qur'an Surah Al-Kahfi: 19: "Demikianlah kami bangunkan mereka itu, supaya mereka sesamanya tanya bertanya, berkata salah seorang diantara mereka itu: berapakah lamanya kita diam disini? Jawab mereka: satu hari atau setengah hari. Mereka berkata: Tuhanmu lebih mengetahui, berapa lamanya kamu diam (disini). Sebab itu suruhlah salah seorang diantara kamu (pergi) kekota dengan membawa uang perak ini, dan hendaklah ia lihat mana makanan yang lebih bersih, kemudian hendaklah dibawanya kemari untuk rezekimu dan hendaklah ia berlaku lemah lembut dan janganlah ia memberi tahukan kepada seorang juapun tentang halmu". ${ }^{26}$

Adapun Rukun Murabahah bil Wakalah adalah: a). Penjual (ba'i); b). Pembeli (musytary); c). Barang yang dibeli (komoditas); d). Harga (tsaman) yang terdiri dari harga beli margin keuntungan dan harga jual; e). Pelaku akad, yaitu muwakil (pemberi kuasa) adalah pihak yang memberikan kuasa kepada pihak lain, dan wakil (penerima kuasa) adalah pihak yang diberi kuasa; f). Objek akad, yaitu taukil (objek yang dikuasakan); g). Shighah, yaitu Ijab dan Qabul. ${ }^{27}$

${ }^{25}$ Nurhadi, Analisis Hukum Perikatan, hlm. 24

${ }^{26}$ Mahmud Yunus, Tafsir Qur'an Karim, (PT. Hidakarya Agung, Jakarta, t.th), hlm. 422; Nurhadi, Analisis Hukum Perikatan, hlm. 24

${ }^{27}$ Kurneawati, op. cit Analisis Perlakuan Akuntansi Piutang Murabahah Pada PT. Bank BRI Syariah KCI Gubeng 
Sedangkan Syarat Murabahah bil (library research) atau studi teks. ${ }^{31}$ Maka Wakalah yaitu: a). Harus digunakan untuk penelitian ini akan lebih memusatkan barang-barang yang halal, barang najis tidak perhatian pada pengkajian-pengkajian sah diperjual-belikan dan barang bukan terhadap teks, dan termasuk jenis penelitian larangan Negara; b). Penjual memberi tahu kualitatif.32 Penelitian kepustakaan dilakukan biaya modal kepada nasabah; c). Kontrak pertama harus sah sesuai dengan rukun yang ditetapkan; d). Kontrak harus bebas dari riba; e). Penjual harus menjelaskan kepada pembeli bila terjadi cacat atas barang sesudah pembelian; f). Penjual harus menyampaikan semua hal yang berkaitan dengan pembelian, misalnya jika pembelian dilakukan secara utang; g). Objek akad harus jelas dan dapat diwakilkan; h). Tidak bertentangan dengan syariat Islam. $^{28}$

\section{METODOLOGI}

Jenis penelitian ini adalah termasuk penelitian kualitatif, karena sifat data yang akan dikumpulkan bercorak kualitatif. ${ }^{29}$ Oleh karena itu data penelitian bersifat naturalis dengan memakai logika induktif dan pelaporannya bersifat deskriptif. ${ }^{30}$ Penelitian ini terfokus pada penelitian kepustakaan

Surabaya, (Penelitian Tidak Diterbitkan, Surabaya, 2011), hlm. 5-6

${ }^{28}$ Ascarya, Akad dan Produk Bank Syariah, (PT RajaGrafindo persada, Jakarta, 2008), hlm. 104; Nurhadi, Analisis Hukum Perikatan, hlm. 26

${ }^{29}$ Lexy J Moleong, Lexy J Moleong, Metodologi Penelitian Kualitatif, (Bandung: Remaja Rosdakarya, 2001), hlm. 11; Imam Suprayogo dan Tobroni, Metodologi Penelitian Sosial-Agama, (Bandung: Remaja Rosdakarya, 2002), hlm. 9; Bungin Burhan, Metodologi Penelitian Kualitatif, (Jakarta: Raja Grafindo Persada, 2004), hlm. 31

${ }^{30}$ Hadari Nawawi, Metode Penelitian Bidang Sosial, (Yogyakarta: Gajah Mada University Press, 2009), hlm. 67; Dedy Mulyana, Metodologi Penelitian Kualitatif, (Bandung: Remaja Rosdakarya, 2005), hlm. 27 karena sumber-sumber datanya, baik yang utama (primary resources) maupun pendukung (secondary resources) seluruhnya adalah teks. ${ }^{33}$ Dalam hal ini sumbernya adalah kitab mausu'ah al-Hadis al-Nabawiyah dan tematiknya (al-Mausu'ah digital sofwer).

\section{Pembahasan}

Penelitian penulis dalam kitab mausu'ah al-hadis al-Nabawiyah, dari persepktif sembilan kitab hadis, yaitu bukhari, musim, abu daud, tirmizi, nasa'i, ibnu majah, ahmad, malik dan al-darimi, maka hadis yang berkaitan dengan kredit murabahah, penulis temukan ada dua hadis dari riwayat bukhari, satu dari riwayat tirmizi, empat dari riwayat nasa'i, tiga dari riawayat ahmad dan dua dari riwayat malik.

\section{Mausu'ah Bukhari ada dua hadis, yaitu No. 1926 dan 6462, sebagai berikut: Mausu'ah Bukhari Hadis pertama:}

\footnotetext{
${ }^{31}$ Iskandar, Metode Penelitian Kualitatif : Aplikasi untuk Penelitian Pendidikan, Hukum, Ekonomi \& Manajemen, Sosial, Humaniora, Politik, Agama dan Filsafat, (Jakarta: Gaung Persada, 2010), hlm. 29; HB Sutopo, Pengantar Penelitian Kualitatif, (Surakarta: Universitas Sebelas Maret Press, 2004), hlm. 17

${ }^{32}$ Hamidi, Metode penelitian kualitatif, (Malang: Universitas Muhammadiyah Malang, 2004), hlm. 13; Neong Muhajir, Metodologi Penelitian Kualitatif, (Yogyakarta: Rake Sarasin, 1998), hlm. 17.

${ }^{33}$ Muhammad Nazir, Metodologi Penelitian, (Jakata: Ghalia Indonesia, 1997), hlm. 58; Sugiyono, Memahami Penelitian Kualitatif; Dilengkapi dengan Contoh Proposal dan Laporan Penelitian, (Bandung: Alfabeta., 2006), hlm. 21
} 
Kitab : Jual beli, Bab: Nabi saw membeli dengan cara tempo, No. Hadis: 1926, sebagai berikut:

حَدَّثَنَا مُعَلَّى بْنُ أَسَدِ حَدَّثَنَا عَبْدُ الْوَاحِدِ حَدَّثَنَا الْأَعْمَشُ قَالَ ذَكَرْنَا

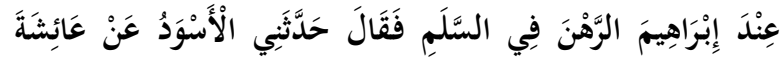

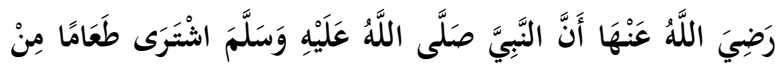
يَهُودِيِّ إِلَى أَجَلِ وَرَهَنَهُ دِرْعًَا مِنْ حَدِيدِ

Artinya: Telah menceritakan kepada kami Mu'alla bin Asad telab menceritakan kepada kami 'Abdul Wabid telah menceritakan kepada kami Al A'masy berkata; Kami membicarakan tentang gadai dalam jual beli kredit (Salam) di hadapan Ibrabim maka dia berkata, telah menceritakan kepada saya Al Aswad dari 'Aisyah radliallabu 'anha babwa Nabi shallallabu 'alaibi wasallam pernah membeli makanan dari orang Yahuid yang akan dibayar Beliau pada waktu tertentu di kemudian hari dan Beliau menjaminkannya (gadai) dengan baju besi (HR. Bukhari No. 1926). ${ }^{34}$

Hadis Bukhari No. 1926 diatas didukung dengan 15 hadis dari beberapa riwayat, yaitu: 7 hadis dari riwayat bukhri, 3 hadis dari riwayat muslim, 2 hadis dari riwayat nasa'i, 1 hadis dari riwayat ibnu majah dan 2 hadis dari riawayat ahmad. Lihat mausu'ah hadis kutub al-Tis'ah berikut ini:

${ }^{34} \mathrm{Abu}$ Abdullah Muhammad bin Ismail AlBukhari bin Ibrahim bin Al-Mughirah bin Bardizbah, Imam al-Bukhari, Sabih Bukhari (Bairut: Darul Ibnu Katsir al-Yammah, t.th), hadis No. 1926 


\begin{tabular}{|c|c|c|c|c|}
\hline No & No Hadis & Perawi & Judul dalam Kitab Hadis & Teks Naskah Arab Kitab Hadis \\
\hline 1 & 1954 & Bukhari & Imam membeli kebutuhannya sendiri & شراء الإمام الحوائج بنفسه \\
\hline 2 & 2049 & Bukhari & $\begin{array}{l}\text { Membeli makanan sampai batas } \\
\text { tertentu }\end{array}$ & شراء الطعام إلى أجل \\
\hline 3 & 2092 & Bukhari & $\begin{array}{l}\text { Sesuatu yang dijadikan jaminan dalam } \\
\text { jual beli salam }\end{array}$ & الكفيل في السلم \\
\hline 4 & 2093 & Bukhari & Gadai dalam jual beli salam & 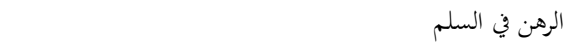 \\
\hline 5 & 2211 & Bukhari & $\begin{array}{l}\text { Orang yang membeli dengan cara } \\
\text { berhutang, sementara ia tidak memiliki } \\
\text { uang pembayaran, atau uang itu tidak } \\
\text { berada di hadapannya }\end{array}$ & اشترى بالدين وليس عنده ثمنه أو ليس بحضرته \\
\hline 6 & 2326 & Bukhari & Menggadaikan baju perang & من رهن درعه \\
\hline 7 & 2330 & Bukhari & $\begin{array}{l}\text { Gadai bagi orang-orang yahudi dan } \\
\text { selainnya }\end{array}$ & الرهن عند اليهود وغيرهم \\
\hline 8 & 3007 & Muslim & Bolehnya gadai & الرهن وجوازه في الحضر كالسفر \\
\hline 9 & 3008 & Muslim & Bolehnya gadai & الرهن وجوازه في الحضر كالسفر \\
\hline 10 & 3009 & Muslim & Bolehnya gadai & الرهن وجوازه في الحضر كالسفر \\
\hline 11 & 4530 & Nasa'i & $\begin{array}{l}\text { Seseorang membeli makanan dengan } \\
\text { pembayaran tangguh dan penjual } \\
\text { meminta gadai (jaminan) }\end{array}$ & الرجل يشتري الطعام إلى أجل ويسترهن البائع منه بالثمن \\
\hline 12 & 4571 & Nasa'i & Jual beli dengan ahli kitab & مبايعة أهل الكتاب \\
\hline 13 & 2427 & $\begin{array}{l}\text { Ibnu } \\
\text { Majah }\end{array}$ & Penggadaian & 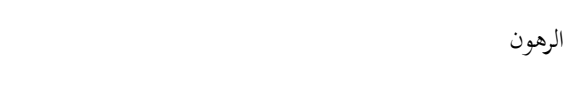 \\
\hline 14 & 23017 & Ahmad & Hadits Sayyidah 'Aisyah Rah & حديث السيدة عائشة رضي الله عنها \\
\hline 15 & 24113 & Ahmad & Lanjutan Musnad yang lalu & باقي المسند السابق \\
\hline
\end{tabular}

\section{Mausu'ah Bukhari Hadis kedua:}

Kitab : siasat mengelak, Bab: Hibah dan Syufah, No. Hadist: 6462, sebagai berikut:

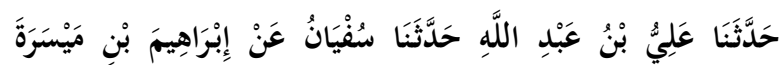

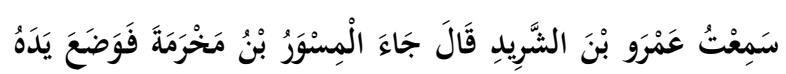

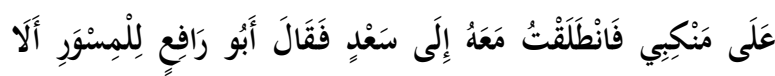

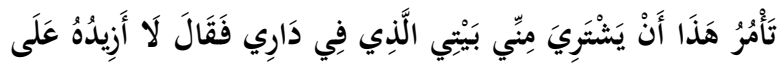

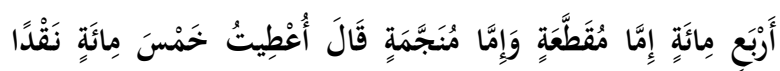

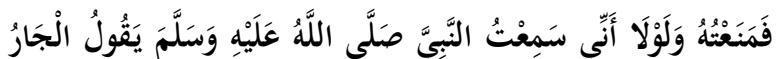

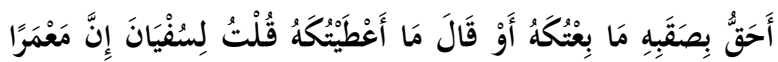
كَمْ يَقُلْ هَكَذَا قَالَ لَكِنَّهُ قَالَ لِي هَكَذَا وَقَالَ بَعْضُ النَّاسِ إِذَا أَرَادَ

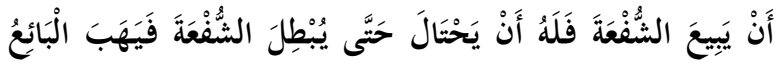

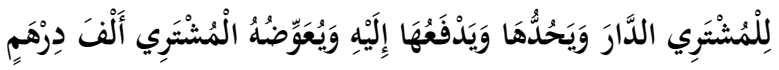
فَلَا يَكُونُ لِلشَّفِيع فِيهَا شُفْعَةُ Artinya: Telah menceritakan kepada kami Ali bin Abdullah telah menceritakan kepada kami Sufyan 
dari Ibrabim bin Maisarah aku mendengar Amru bin Syarid mengatakan, Miswar bin makbramah datang dan meletakkan tangannya di pundakku. Kemudian aku berangkat bersamanya menuju ke Sa'd. Lantas Abu Rafi' mengatakan kepada Miswar; 'Tidakeah engkau surub orang ini untuk membeli rumabku yang berada di pekaranganku?' ia berkata; 'Saya tidak menambahnya melebihi empat ratus, baik secara kontan atau kredit.' Abu rafi' mengatakan; 'Aku telab diberi lima ratus secara kontan, namun aku menolaknya, kalaulah aku tidak mendengar Nabi shallallabu 'alaibi wasallam bersabda: "Tetangga lebib berbak terhadap dinding tetangganya, " niscaya aku tidak akan menjualnya kepadamu, -atau ia mengatakan dengan redaksi; 'niscaya tak akan memberikannya kepadamu'.- Saya berkata kepada Ma'mar; Ma'mar tidak mengatakan demikian, namun dia mengatakan kepadaku sedemikian dan mengatakan; Jika seseorang ingin menjual syuf'ah, maka ia boleh melakukan siasat sehingga membatalkan syuf'ah, dan penjual memberikan rumah kepada si pembeli, memberi batasan (waktu dan nilai) dan menyerabkannya kepada si pembeli, dan si pembeli menggantinya dengan seribu dirham, sehingga orang yang mempunyai syuf'ah tidak mempunyai syuf'ab lagi. (HR. Bukhari No. 6462). ${ }^{35}$

Hadis Bukhari No. 6462 diatas didukung dengan 12 hadis dari beberapa riwayat, yaitu: 1 hadis dari riwayat bukhri, 1 hadis dari riwayat abu daud, 2 hadis dari riwayat nasa'i, 2 hadis dari riwayat ibnu majah dan 6 hadis dari riawayat ahmad. Lihat mausu'ah hadis kutub al-Tis'ah berikut ini:

${ }^{35} \mathrm{Abu}$ Abdullah Muhammad bin Ismail AlBukhari bin Ibrahim bin Al-Mughirah bin Bardizbah, Imam al-Bukhari, Sahib Bukhari (Bairut: Darul Ibnu Katsir al-Yammah, t.th), hadis No. 6462 


\begin{tabular}{|c|c|c|c|c|}
\hline No & No Hadis & Perawi & Judul dalam Kitab Hadis & Teks Naskah Arab Kitab Hadis \\
\hline 1 & 6466 & Bukhari & $\begin{array}{l}\text { Siasat pengumpul zakat agar } \\
\text { memperoleh hadiah }\end{array}$ & احتيال العامل ليهدى له \\
\hline 2 & 3051 & Abu Daud & Penjelasan tentang Syuf'ah & في الشفعة \\
\hline 3 & 4623 & Nasa'i & Syuf'ah dan hukumnya & ذكر الشفعة وأحكامها \\
\hline 4 & 4624 & Nasa'i & Syuf'ah dan hukumnya & ذكر الشفعة وأحكامها \\
\hline 5 & 2486 & Ibnu Majah & Syuf'ah untuk tetangga & الشفعة بالجوار \\
\hline 6 & 2487 & Ibnu Majah & Syuf'ah untuk tetangga & الشفعة بالجوار \\
\hline 7 & 18642 & Ahmad & $\begin{array}{l}\text { Hadits Asy Syarid bin Suwaid Ats } \\
\text { Tsaqafi Ra }\end{array}$ & ق ق قفي رضي اللّ تعالى عنه \\
\hline 8 & 18643 & Ahmad & $\begin{array}{l}\text { Hadits Asy Syarid bin Suwaid Ats } \\
\text { Tsaqafi Ra }\end{array}$ & حديث الشريد بن سويد الثقفي رضي الله تعالى عنه \\
\hline 9 & 18658 & Ahmad & $\begin{array}{l}\text { Hadits Asy Syarid bin Suwaid Ats } \\
\text { Tsaqafi Ra }\end{array}$ & حديث الشريد بن سويد الثقفي رضي الله تعالى عنه \\
\hline 10 & 19323 & Ahmad & $\begin{array}{l}\text { Dan dari Hadits Samurah bin } \\
\text { Jundub dari Nabi saw }\end{array}$ & وسلم حمن حديث سمرة بن جندب عن النبي صلى الله عليه \\
\hline 11 & 19377 & Ahmad & $\begin{array}{l}\text { Dan dari Hadits Samurah bin } \\
\text { Jundub dari Nabi saw }\end{array}$ & وسلم حمن حديث سمرة بن جندب عن النبي صلى الله عليه \\
\hline 12 & 25927 & Ahmad & Hadits Abu Rafi' Ra & حديث أبي رافع رضي الله عنه \\
\hline
\end{tabular}

Mausu'ah Tirmizi ada satu hadis, yaitu No. 1152, sebagai berikut:

\section{Mausu'ah Tirmizi}

Kitab : Jual beli, Bab: Larangan dua akad dalam satu jual-beli, No. Hadist: 1152

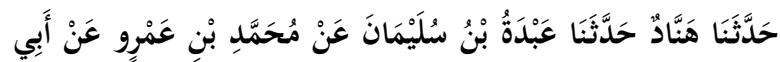

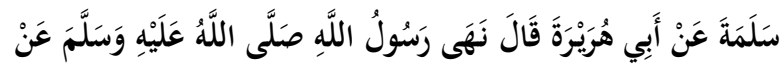

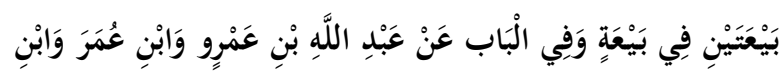

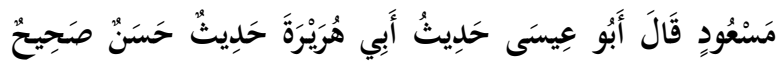

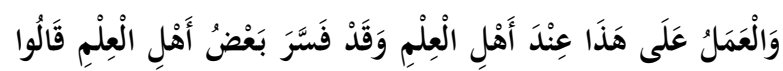

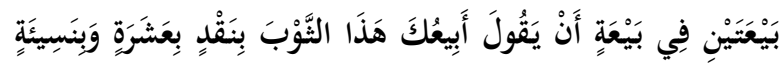

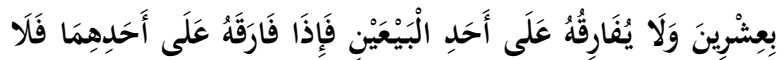

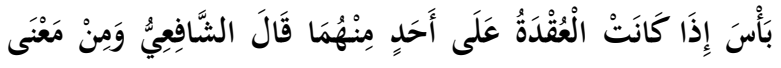

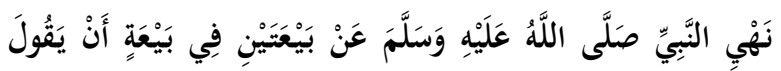

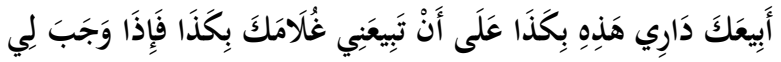

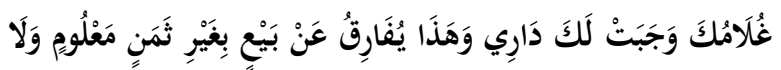

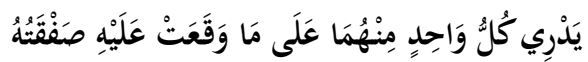

Artinya: Telah menceritakan kepada kami Hannad telah menceritakan kepada kami Abdah bin Sulaiman dari Mubammad bin Amru dari Abu Salamah dari Abu Hurairah ia berkata; Rasulullah shallallahu 'alaibi wasallam melarang melakukan dua penjualan dalam satu kali transaksi. Dalam hal ini ada hadits serupa dari 
Abdullab bin Amru. Ibnu Umar dan Ibnu Mas'ud. Abu Isa berkata; Hadits Abu Hurairah adalah hadits hasan shahib dan menjadi pedoman amal menurut para ulama. Sebagian ulama menafsirkan hadits ini, mereka mengatakan; maksud Dua penjualan dalam satu transaksi adalah perkataan seseorang; Aku menjual pakaian ini kepadamu dengan tunai seharga sepuluh dan kredit seharga dua pulub tanpa memisabkannya atas salah satu dari dua transaksi. Jika ia memisabkannya atas salah satu dari kedua transaksi tersebut maka tidak apa-apa selama akadnya jatub pada salab satu dari keduanya. Asy Syafi'i berkata; Termasuk makna dari larangan Rasulullah shallallahu 'alaibi wasallam tentang dua transaksi dalam satu kali jual beli adalah perkataan seseorang; Aku menjual rumabku kepadamu dengan harga sekian dengan syarat kamu menjual budakmu kepadaku dengan harga sekian. Jika budakmu sudah menjadi milikk. berarti rumabku juga menjadi milikemu, tata cara jual beli seperti ini berbeda dengan tata cara jual beli barang yang tidak diketahui harganya dan salah satu dari keduanya (penjual dan pembeli) tidak mengetabui tansaksi yang ia tujukan. (HR. Tirmizi No. 1152). ${ }^{36}$

Hadis Tirmizi No. 1152 diatas didukung dengan 5 hadis dari beberapa riwayat, yaitu: 1 hadis dari riwayat nasa'i, 1 hadis dari riwayat ibnu majah dan 3 hadis dari riawayat ahmad. Lihat mausu'ah hadis kutub al-Tis'ah berikut ini:

${ }^{36} \mathrm{Abu}$ 'Isa muhammad bin isa bin surrah alTurmudzi Ibn Musa Ibn Adh-Dhahak Al-Sulami AlBughi Al-Tirmidzi, Al-Sunan Al-Tirmizi (Lebanon: Dar al-Hadis, t.th), hadis No.1152 


\begin{tabular}{|c|c|c|c|c|}
\hline No & No Hadis & Perawi & Judul dalam Kitab Hadis & Teks Naskah Arab Kitab Hadis \\
\hline 1 & 4553 & Nasa'i & $\begin{array}{l}\text { Dua pembelian dalam satu } \\
\text { pembelian }\end{array}$ & بيعتين في بيعة وهو أن يقول أبيعك هذه السلعة بمائة \\
\hline 2 & 2186 & $\begin{array}{l}\text { Ibnu } \\
\text { Majah }\end{array}$ & $\begin{array}{l}\text { Larangan jual beli al Hashah dan } \\
\text { jual beliau gharar }\end{array}$ & النهي عن بيع الحصاة وبيع الغرر \\
\hline 3 & 6339 & Ahmad & $\begin{array}{l}\text { Musnad Abdullah bin 'Amru bin Al } \\
\text { 'Ash Rahuma }\end{array}$ & مسند عبد الله بن عمرو بن العاص رضي الله تعالى عنهما \\
\hline 4 & 9214 & Ahmad & Musnad Abu Hurairah Ra & مسند أبي هريرة رضي الله عنه \\
\hline 5 & 10131 & Ahmad & Musnad Abu Hurairah Ra & مسند أبي هريرة رضي الله عنه \\
\hline
\end{tabular}

Mausu'ah Nasa'i ada empat hadis, yaitu No. 3875, 4504, 4541, 4571, sebagai berikut:

\section{Mausu'ah Nasa'i hadis pertama:}

Kitab : Iman dan nadzar, Bab: Perbedaan lafadh yang ma"tsur tentang Muzaro'ah, No. Hadist: 3875

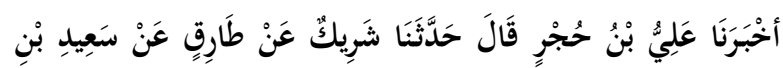

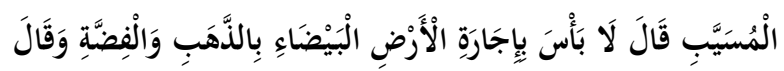

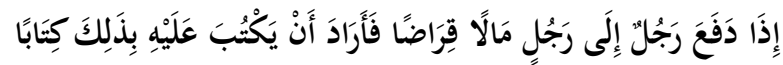

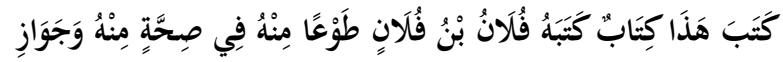

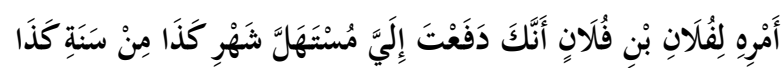
عَشَرَةَ آلَالَفِ دِرْهَمِ وُضْحَا جِيَادًا وَزْنَ سَبْعَةٍ قِرَاضًا عَلَى تَقْوَى اللَّهِ

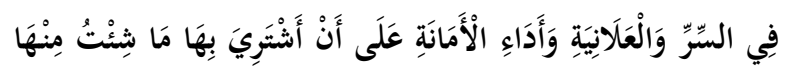

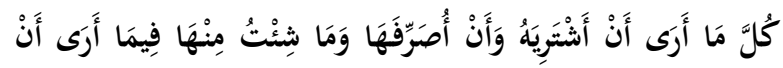

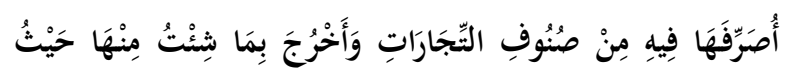

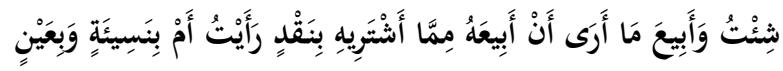

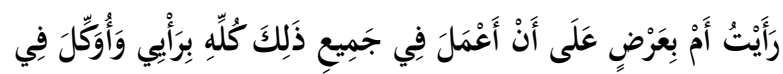

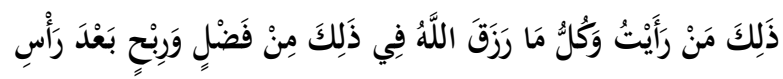

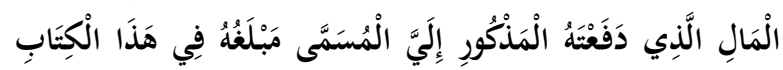

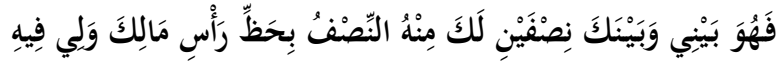

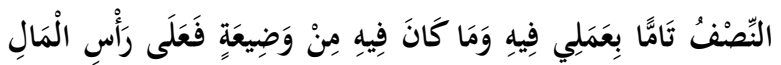

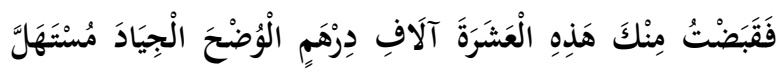

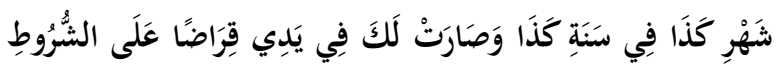

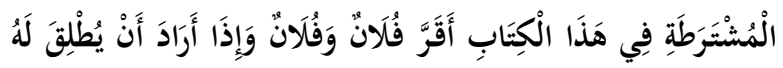

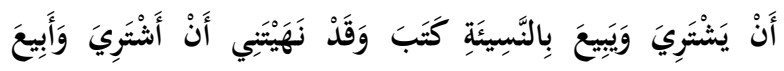
بالنَّسيَّة

Artinya: Telah mengabarkan kepada kami 'Ali bin Hujr telah menceritakan kepada kami Syarik. dari Thariq dari Sa'id bin Al Musayyab, dia berkata; "Tidak mengapa menyewakan tanah kosong dengan upah emas atau perak." Dia juga berkata; "Jika seseorang membayar harta kepada orang lain dengan qirod (pemberian modal untuk berdagang dengan memperoleh bagian laba) dan dia ingin menuliskannya dalam surat lalu dia menulis; Ini adalah surat yang ditulis oleh fulan bin fulan dengan kerelaan darinya dalam keadaan sehat dan lisensinya untuk Fulan bin Fulan, bahwa engkau telab menyerabkan kepadaku pada permulaan bulan dari tabun ini, sebanyak sepuluh ribu dirham secara jelas dan baik dengan berat tujuh qiradh atas dasar ketakwaan kepada Allah baik dalam keadaan tersembunyi ataupun terang-terangan, serta 
menunaikan amanah agar saya membeli dengannya menurut kehendake.u segala apa yang ingin saya beli, dan aku akan mengaturnya sekiranya saya pandang perlu untuk mengaturnya dari berbagai jenis perdagangan, dan akan aku keluarkan apa yang saya kehendaki kemana saja yang saya kehendaki dan menjual apa yang ingin saya jual dari barang yang telab saya beli, baik secara kontan atau kredit, baik dengan uang atau dengan barang dengan dasar saya mengerjakan semua itu sesuai pendapatku, dan saya akan mewakilkan dalam itu kepada orang yang kehendaki, dan setiap apa yang dirizqikan Allah dalam hal itu berupa kelebihan dan keuntungan diluar modal tersebut yang telah engkau serabkan kepadaku yang tertera banyaknya, didalam surat ini, maka hal itu dibagi antara saya dan engkau menjadi dua bagian, untukmu setengah sesuai dengan bagian modalmu, dan untukku setengah sesuai dengan pekerjaanku secara penuh, jika ada sesuatu yang hilang maka hal itu menjadi tanggungan modal. Saya terima sebanyak sepulub ribu dirham secara jelas dan baik pada permulaan bulan ini pada tabun ini, dan menjadi qiradh milikmu yang ada padaku dengan persyaratan yang tercantum dalam surat ini. Telah menyatakan Fulan dan Fulan. Jika ia ingin membebaskannya untuk membeli dan menjual secara kredit, maka ia menulis; dan engkau telah melarangku untuk membeli dan menjualnya dengan kredit." (HR. Nasa'i No. 3875). ${ }^{37}$

Hadis nasa'i diatas tidak ada hads penguatnya.

\section{Mausu'ah Nasa'i hadis kedua:}

Kitab: Jual-beli, Bab: Membeli perak dengan emas atau membeli emas dengan perak, No. Hadist: 4504

${ }^{37} \mathrm{Abu}$ 'Abdirrahman ahmad bin su'aib bin ali bin bahr bin sinan bin dinar an-Nasai al-Kurasani, AlSunan al-Nasa'i (Cairo: Dar Ilmi, t.th), hadis No. 3875

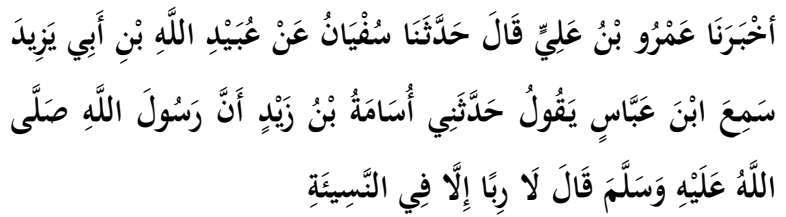

Artinya: Telah mengabarkan kepada kami 'Amru bin Ali telah menceritakan kepada kami Sufyan dari 'Ubaidullab bin Abu Yazid, dia telah mendengar Ibnu Abbas berkata; "Telab menceritakan kepadaku Usamah bin Zaid babwa Rasulullah shallallahu 'alaibi wasallam bersabda: "Tidak ada riba kecuali di dalam kredit." (HR. Nasa'i No. 4504). ${ }^{38}$

Hadis Nasa'i No. 4504 diatas didukung dengan 8 hadis dari beberapa riwayat, yaitu: 1 hadis dari muslim dan 7 hadis dari riawayat ahmad. Lihat mausu'ah hadis kutub al-Tis'ah berikut ini: 


\begin{tabular}{|c|c|c|c|c|}
\hline No & No Hadis & Perawi & Judul dalam Kitab Hadis & Teks Naskah Arab Kitab Hadis \\
\hline 1 & 2990 & Muslim & $\begin{array}{l}\text { Menjual makanan dengan kadar } \\
\text { yang sama }\end{array}$ & 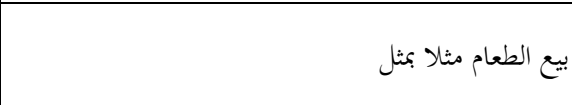 \\
\hline 2 & 20748 & Ahmad & $\begin{array}{l}\text { Hadits Usamah bin Zaid kecintaan } \\
\text { Rasulullah saw }\end{array}$ & وسلم ريث أسامة بن زيد حب رسول الله صلى الله عليه \\
\hline 3 & 20755 & Ahmad & $\begin{array}{l}\text { Hadits Usamah bin Zaid kecintaan } \\
\text { Rasulullah saw }\end{array}$ & وسلم ريث أسامة بن زيد حب رسول الله صلى الله عليه \\
\hline 4 & 20767 & Ahmad & $\begin{array}{l}\text { Hadits Usamah bin Zaid kecintaan } \\
\text { Rasulullah saw }\end{array}$ & وسلم ريث أسامة بن زيد حب رسول الله صلى الله عليه \\
\hline 5 & 20779 & Ahmad & $\begin{array}{l}\text { Hadits Usamah bin Zaid kecintaan } \\
\text { Rasulullah saw }\end{array}$ & وسلم ريث أسامة بن زيد حب رسول الله صلى الله عليه \\
\hline 6 & 20796 & Ahmad & $\begin{array}{l}\text { Hadits Usamah bin Zaid kecintaan } \\
\text { Rasulullah saw }\end{array}$ & وسلم \\
\hline 7 & 20797 & Ahmad & $\begin{array}{l}\text { Hadits Usamah bin Zaid kecintaan } \\
\text { Rasulullah saw }\end{array}$ & وسلم \\
\hline 8 & 20816 & Ahmad & $\begin{array}{l}\text { Hadits Usamah bin Zaid kecintaan } \\
\text { Rasulullah saw }\end{array}$ & وسلم \\
\hline
\end{tabular}

\section{Mausu'ah Nasa'i hadis ketiga:}

Kitab: Jual-beli, Bab: Menjual hewan dengan hewan yang dibayarkan secara tangguh, No. Hadist: 4541

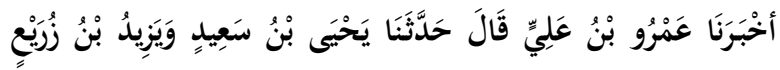

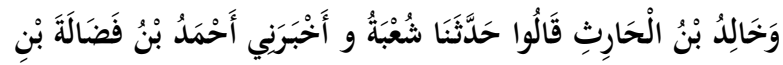

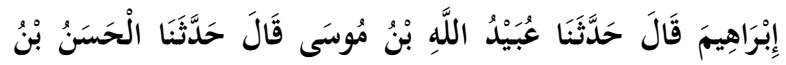

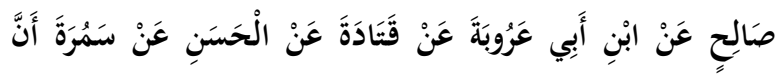

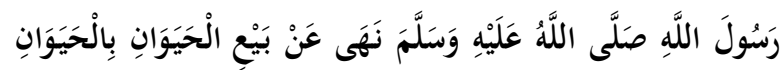

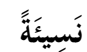

Artinya: Telah mengabarkan kepada kami 'Amru bin Ali, ia berkata; telah menceritakan kepada kami Yabya bin Sa'id dan Yarid bin Zurai' dan Khalid bin Al Harits mereka berkata; telah menceritakan kepada kami Syu'bah dan telah mengabarkan kepadaku Ahmad bin Fadhalah bin Ibrabim, ia berkata; telah menceritakan kepada kami 'Ubaidullah bin Musa, ia berkata; telah menceritakan kepada kami Al Hasan bin Shalih dari Ibnu Abu 'Arubah dari Qatadah dari Al Hasan dari Samurab babwa Rasulullab shallallabu 'alaibi wasallam melarang dari menjual hewan dengan bewan secara kredit. (HR. Nasa'i No. 4541). ${ }^{39}$

${ }^{39} \mathrm{Abu}$ 'Abdirrahman ahmad bin su'aib bin ali bin bahr bin sinan bin dinar an-Nasai al-Kurasani, AlSunan al-Nasa'i (Cairo: Dar Ilmi, t.th), hadis No. 4541 
Hadis Nasa'i No. 4541 diatas majah, 6 hadis dari riawayat ahmad dan 1 dari didukung dengan 12 hadis dari beberapa riwayat malik. Lihat mausu'ah hadis kutub alriwayat, yaitu: 2 hadis dari riwayat abu daud, Tis'ah berikut ini:

1 dari riwayat tirmizi, 2 dari riwayat ibnu

\begin{tabular}{|c|c|c|c|c|}
\hline No & No Hadis & Perawi & Judul dalam Kitab Hadis & Teks Naskah Arab Kitab Hadis \\
\hline 1 & 2912 & Abu Daud & $\begin{array}{l}\text { Hewan dengan hewan dengan } \\
\text { nasi`ah }\end{array}$ & | في الحيوان بالحيوان نسيئة \\
\hline 2 & 2916 & Abu Daud & Kurma dengan kurma & 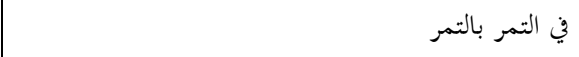 \\
\hline 3 & 1158 & Tirmidzi & $\begin{array}{l}\text { Dimakruhkan jual beli hewan } \\
\text { dengan hewan secara } \\
\text { ditangguhkan }\end{array}$ & ما جاء في كراهية بيع الحيوان بالحيوان نسيئة \\
\hline 4 & 2186 & $\begin{array}{l}\text { Ibnu } \\
\text { Majah }\end{array}$ & $\begin{array}{l}\text { Larangan jual beli al Hashah dan } \\
\text { jual beliau gharar }\end{array}$ & عن بيع الحصاة وبيع الغرر \\
\hline 5 & 2261 & $\begin{array}{l}\text { Ibnu } \\
\text { Majah }\end{array}$ & $\begin{array}{l}\text { Jual beli hewan dengan hewan } \\
\text { secara nasiah (tempo) }\end{array}$ & 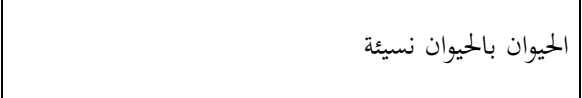 \\
\hline 6 & 13812 & Ahmad & Musnad Jabir bin Abdullah Ra & سند جابر بن عبد الله رضي الله تعالى عنه \\
\hline 7 & 19284 & Ahmad & $\begin{array}{l}\text { Dan dari Hadits Samurah bin } \\
\text { Jundub dari Nabi saw }\end{array}$ & لم حمديث سمرة بن جندب عن النبي صلى الله عليه \\
\hline 8 & 19349 & Ahmad & $\begin{array}{l}\text { Dan dari Hadits Samurah bin } \\
\text { Jundub dari Nabi saw }\end{array}$ & لمن حلميث سمرة بن جندب عن النبي صلى الله عليه \\
\hline 9 & 19367 & Ahmad & $\begin{array}{l}\text { Dan dari Hadits Samurah bin } \\
\text { Jundub dari Nabi saw }\end{array}$ & لم حلم حديث سمرة بن جندب عن النبي صلى الله عليه \\
\hline 10 & 19388 & Ahmad & $\begin{array}{l}\text { Dan dari Hadits Samurah bin } \\
\text { Jundub dari Nabi saw }\end{array}$ & وسلم ومديث سمرة بن جندب عن النبي صلى الله عليه \\
\hline 11 & 20037 & Ahmad & Hadits Jabir bin Samurah Ra & حديث جابر بن سمرة رضي الله عنه \\
\hline 12 & 1175 & Malik & Jual beli penipuan & 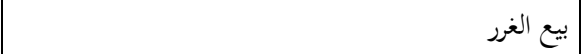 \\
\hline
\end{tabular}

\section{Mausu'ah Nasa'i hadis keempat:}

Kitab: Jual-beli, Bab: Jual beli dengan ahli kitab, No. Hadist: 4571

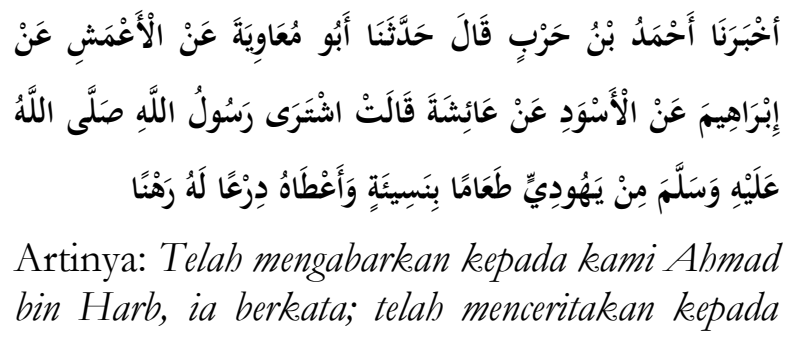


kami Abu Mu'awiyah dari Al A'masy dari Ibrahim dari Al Aswad dari Aisyah, ia berkata; Rasulullah shallallabu 'alaibi wasallam membeli makanan dengan kredit dari seorang Yabudi, dan beliau memberikan kepadanya baju zirah beliau sebagai gadaian. (HR. Nasa'i No. 4571). ${ }^{40}$

Hadis Nasa'i No. 4571 diatas didukung dengan 11 hadis dari beberapa riwayat, yaitu: 6 hadis dari riwayat bukhari, 3 dari riwayat muslim dan 2 hadis dari riawayat ahmad. Lihat mausu'ah hadis kutub al-Tis'ah berikut ini:

${ }^{40} \mathrm{Abu}$ 'Abdirrahman ahmad bin su'aib bin ali bin bahr bin sinan bin dinar an-Nasai al-Kurasani, AlSunan al-Nasa'i (Cairo: Dar Ilmi, t.th), hadis No. 4571 


\begin{tabular}{|c|c|c|c|c|}
\hline No & No Hadis & Perawi & Judul dalam Kitab Hadis & Teks Naskah Arab Kitab Hadis \\
\hline 1 & 1926 & Bukhari & $\begin{array}{l}\text { Nabi saw membeli dengan cara } \\
\text { tempo }\end{array}$ & شراء النبي صلى الله عليه وسلم بالنسيئة \\
\hline 2 & 1954 & Bukhari & $\begin{array}{l}\text { Imam membeli kebutuhannya } \\
\text { sendiri }\end{array}$ & شراء الإمام الحوائج بنفسه \\
\hline 3 & 2092 & Bukhari & $\begin{array}{l}\text { Sesuatu yang dijadikan jaminan } \\
\text { dalam jual beli salam }\end{array}$ & المفيل في السلم \\
\hline 4 & 2093 & Bukhari & Gadai dalam jual beli salam & الرهن في السلم \\
\hline 5 & 2211 & Bukhari & $\begin{array}{l}\text { Orang yang membeli dengan cara } \\
\text { berhutang, sementara ia tidak } \\
\text { memiliki uang pembayaran, atau } \\
\text { uang itu tidak berada di } \\
\text { hadapannya }\end{array}$ & من اشترى بالدين وليس عنده ثُنه أو ليس بحضرته \\
\hline 6 & 2330 & Bukhari & $\begin{array}{l}\text { Gadai bagi orang-orang yahudi } \\
\text { dan selainnya }\end{array}$ & الرهن عند اليهود وغيرهم \\
\hline 7 & 3007 & Muslim & Bolehnya gadai & الرهن وجوازه في الحضر كالسفر \\
\hline 8 & 3008 & Muslim & Bolehnya gadai & الرهن وجوازه في الحضر كالسفر \\
\hline 9 & 3009 & Muslim & Bolehnya gadai & الرهن وجوازه في الحضر كالسفر \\
\hline 10 & 23017 & Ahmad & Hadits Sayyidah 'Aisyah Rah & حديث السيدة عائشة رضي الله عنها \\
\hline 11 & 24113 & Ahmad & Lanjutan Musnad yang lalu & باقي المسند السابق \\
\hline
\end{tabular}

Mausu'ah Ahmad ada tiga hadis, yaitu No. 3595, 15663, 15675, sebagai berikut:

\section{Mausu'ah Ahmad hadis pertama:}

Kitab: Musnad sahabat yang banyak meriwayatkan hadits, Bab: Musnad Abdullah bin Mas'ud Radliyallahu ta'ala 'anhu, No. Hadist: 3595

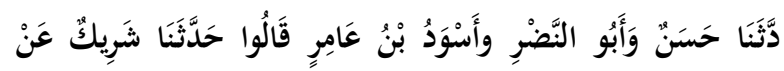

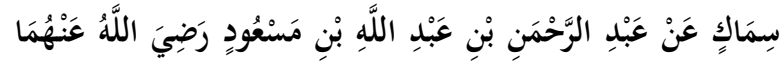

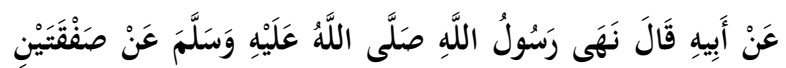

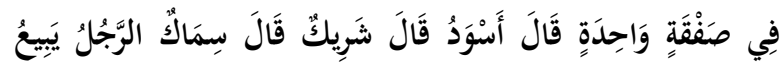

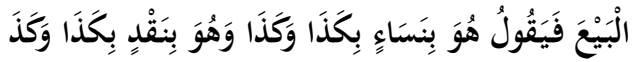

Artinya: Telah menceritakan kepada kami Hasan dan Abu Nadlr dan Aswad bin Amir mereka berkata; Telah menceritakan kepada kami Syarik dari Simak dari Abdurrabman bin Abdullab bin Mas'ud radliallabu 'anbuma dari ayahnya berkata; Rasulullah shallallahu 'alaibi wasallam melarang dua transaksi dalam satu akad. Aswad berkata; Syarik berkata; Simak berkata; Seorang laki-laki menjual barang jualan seraya mengatakan; Ia dengan kredit sekian dan sekian dan dengan tunai sekian dan sekian. (HR. Ahmad No. 3595). ${ }^{41}$

${ }^{41}$ Ahmad bin Muhammad ibn Hanbal alSyaibany, Al-Musnad Ibnu al-Hambali (Lebanon: Dar alHadis, t.th), hadis No. 15663 
Hadis diatas tidak memiliki hadis penguatnya.

\section{Mausu'ah Ahmad hadis kedua:}

Kitab: Musnad penduduk Madinah, Bab: Hadits Hisyam bin 'Amir Al Anshari Radliyallahu ta'ala 'anhu, No. Hadist: 15663

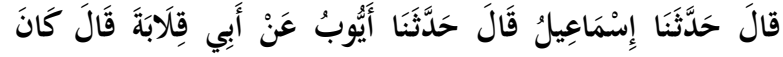

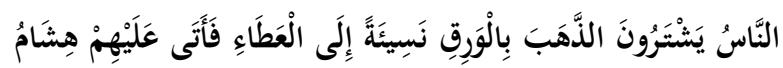

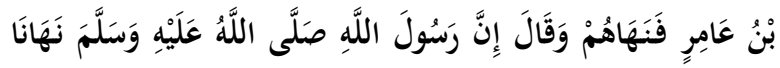

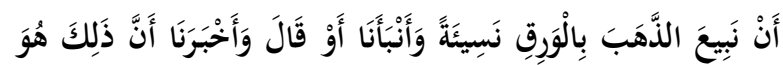

Artinya: Abmad bin Hanbal) berkata; telah menceritakan kepada kami Isma'il berkata; telah menceritakan kepada kami Ayyub dari Abu Qilabah berkata; orang-orang membeli emas dengan mata uang secarakredit dengan syarat ada penambahan, kemudian hari Hisyam bin 'Amir datang kepada mereka, lalu melarang transaksi semacam itu dan berkata; Rasulullah shallallabu'alaibiwasallam melarang kita untuk menjual emas dengan mata uang secara kreditdan bersyarat penambahan, ia beritakan itu adalah riba." (HR. Ahmad No. 15663).

Hadis diatas tidak memiliki hadis penguatnya.

\section{Mausu'ah Ahmad hadis ketiga:}

Kitab: Musnad penduduk Madinah, Bab: Hadits Hisyam bin 'Amir Al Anshari Radliyallahu ta'ala 'anhu, No. Hadist: 15675

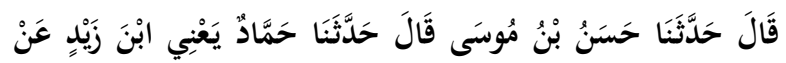

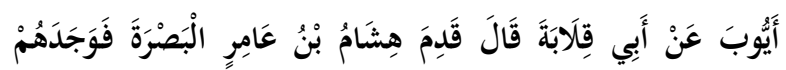

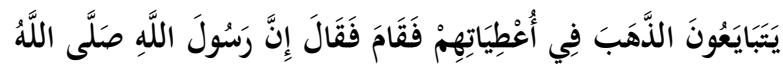

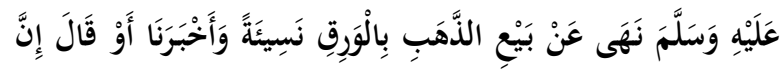

ذَلِكَ هُوَ الرِّبَا
Artinya: (Ahmad bin Hanbal) berkata; telah menceritakan kepada kami Hasan bin Musa berkata; telah menceritakan kepada kami Hammad yaitu Ibnu Zaid, dari Ayyub dari Abu Qilabah berkata; Hisyam bin 'Amir datang ke Basrah, lalu mendapati mereka saling berjual beli emas dalam tempat pertukaran mereka, lalu dia berdiri dan berkata; Rasulullab shallallabu'alaibiwasallam melarang juAl beli emas dengan uang secara kredit, dan telah mengabarkan kepada kami atau berkata; itu adalah riba. (HR. Ahmad No. 15675). ${ }^{42}$ Hadis diatas tidak memiliki hadis penguatnya

Mausu'ah Malik ada dua hadis, yaitu No. 1148, 1182, sebagai berikut:

\section{Mausu'ah Malik hadis pertama:}

Kitab: Jual-beli, Bab: Dari kakeknya, Malik bin Abu Amir, bahwa Utsman bin Affa, No. Hadist: 1148

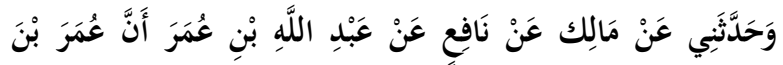

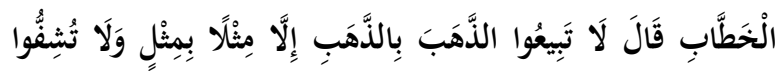

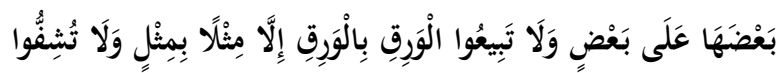

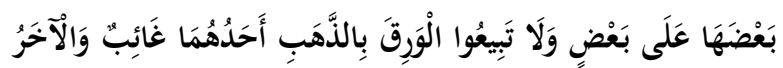

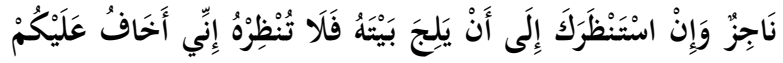
الرَّمَاءَ وَالَرَمَاءُ هُوَ الرِّبَا

Artinya: Telah menceritakan kepadaku dari Malik dari Nafi' dari Abdullah bin Umar bahwa Umar bin Khattab berkata; "Janganlah kalian menjual emas dengan emas kecuali sebanding, dan janganlah kalian melebibkan sebagian atas sebagian yang lain. Janganlah kalian menjual perak dengan perak kecuali sebanding, dan janganlah kalian melebibkan sebagian atas sebagian yang lain. Janganlab kalian menjual perak dengan emas, yang satu kredit dan yang lain cash. Jika ada seseorang yang meminta

${ }^{42}$ Ahmad bin Muhammad ibn Hanbal alSyaibany, Al-Musnad Ibnu al-Hambali (Lebanon: Dar alHadis, t.th), hadis No. 15675 
penangguhan kepadamu hingga ia masuk ke dalam rumabnya maka janganlab engkau beri penangguhan, karena aku khawatir kalian akan mendapat tambahan, sebab tambahan adalab riba." (HR. Malik No. 1148). ${ }^{43}$

Hadis Malik No. 1148 diatas didukung dengan 21 hadis dari beberapa riwayat, yaitu: 3 hadis dari riwayat bukhari, 4 dari riwayat muslim, 1 dari riwayat abu daud, 2 dari riwayat tirmizi, 1 dari riwayat nasa'i, 1 dari riwayat ibnu majah, 8 hadis dari riawayat ahmad dan 1 dari riwayat malik. Lihat mausu'ah hadis kutub al-Tis'ah berikut ini:

${ }^{43}$ Abdullah Malik ibn Anas ibn Malik ibn Abi Amir ibn Amr ibn al-Haris ibn Gaiman ibn Husail ibn Amr ibn al-Haris al-Asbahi al-Madani, Al-Mua'tha' Imam Malik (Beirut: Dar Fikri, t.th), hadis No. 1148 


\begin{tabular}{|c|c|c|c|c|}
\hline No & No Hadis & Perawi & Judul dalam Kitab Hadis & Teks Naskah Arab Kitab Hadis \\
\hline 1 & 2029 & Bukhari & Menjual emas dengan emas & بيع الذهب بالذهب \\
\hline 2 & 2030 & Bukhari & Menjual perak dengan perak & بيع الفضة بالفضة \\
\hline 3 & 2031 & Bukhari & Menjual perak dengan perak & 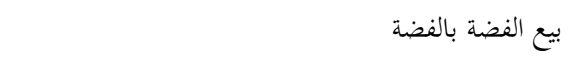 \\
\hline 4 & 2964 & Muslim & Riba & 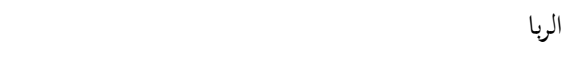 \\
\hline 5 & 2965 & Muslim & Riba & الربا \\
\hline 6 & 2966 & Muslim & Riba & 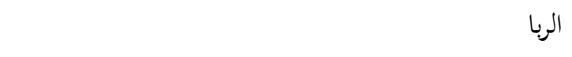 \\
\hline 7 & 2980 & Muslim & $\begin{array}{l}\text { Menjual kalung yang di dalamnya } \\
\text { ada mutiara dan emas }\end{array}$ & بيع القلادة فيها خرز وذهب \\
\hline 8 & 2910 & $\begin{array}{l}\text { Abu } \\
\text { Daud }\end{array}$ & $\begin{array}{l}\text { Hiasan pedang dijual dengan } \\
\text { dirham }\end{array}$ & في حلية السيف تباع بالدراهم \\
\hline 9 & 1161 & Tirmidzi & $\begin{array}{l}\text { Gandum dengan gandum dengan } \\
\text { takaran sama, dimakruhkan } \\
\text { melebihi }\end{array}$ & ن الحنطة بالحنطة مثلا بمثل كراهية التفاضل \\
\hline 10 & 1162 & Tirmidzi & Sharf & ما جاء في الصرف \\
\hline 11 & 4494 & Nasa'i & Membeli emas dengan emas & بيع الذهب بالذهب \\
\hline 12 & 18 & $\begin{array}{l}\text { Ibnu } \\
\text { Majah }\end{array}$ & $\begin{array}{l}\text { Mengagungkan hadits Rasulullah } \\
\text { saw }\end{array}$ & تعظيم حديث رسول الله صلى الله عليه وسلم والتغليظ \\
\hline 13 & 10583 & Ahmad & Musnad Abu Sa'id Al Khudri Ra & مسند أبي سعيد الخدري رضي الله تعالى عنه \\
\hline 14 & 10639 & Ahmad & Musnad Abu Sa'id Al Khudri Ra & مسند أبي سعيد الخدري رضي الله تعالى عنه \\
\hline 15 & 11070 & Ahmad & Musnad Abu Sa'id Al Khudri Ra & مسند أبي سعيد الخدري رضي الله تعالى عنه \\
\hline 16 & 11130 & Ahmad & Musnad Abu Sa'id Al Khudri Ra & مسند أبي سعيد الخدري رضي الله تعالى عنه \\
\hline 17 & 11156 & Ahmad & Musnad Abu Sa'id Al Khudri Ra & مسند أبي سعيد الخدري رضي الله تعالى عنه \\
\hline 18 & 11275 & Ahmad & Musnad Abu Sa'id Al Khudri Ra & مسند أبي سعيد الخدري رضي الله تعالى عنه \\
\hline 19 & 11347 & Ahmad & $\begin{array}{l}\text { Musnad Abu Sa'id Al Khudri } \\
\text { Ra }\end{array}$ & مسند أبي سعيد الخدري رضي الله تعالى عنه \\
\hline 20 & 22843 & Ahmad & $\begin{array}{l}\text { Hadits Fadlalah bin 'Ubaid Al } \\
\text { Anshari Ra }\end{array}$ & مسند فضالة بن عبيد الأنصاري رضي الله عنه \\
\hline 21 & 1149 & Malik & $\begin{array}{l}\text { Dari kakeknya, Malik bin Abu } \\
\text { Amir, bahwa Utsman bin } \\
\text { Affan... }\end{array}$ & عن جده مالك بن أبي عامر أن عثمان بن عفان \\
\hline
\end{tabular}




\section{Mausu'ah Malik hadis kedua:}

Kitab: Jual-beli, Bab: Utang dan pengalihan utang, No. Hadist: 1182

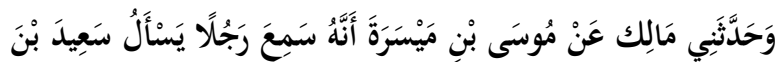

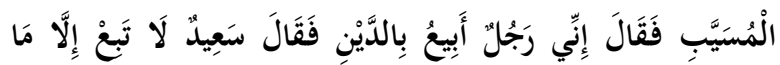

$$
\text { آوَيْتَ إِلَى رَحْلِكَ }
$$

Artinya: Telah menceritakan kepadaku Malik dari Musa bin Maisarah ia mendengar seorang laki-laki bertanya kepada Sa'id bin Musayyab; "Saya adalah orang yang biasa berjualan dengan cara kredit." Sa'id menjawab; "Janganlah kamu menjual barang kecuali apa yang kamu bawa ke rumahmu." (HR. Malik No. 1182). ${ }^{44}$

Hadis Malik No. 1182 diatas didukung dengan 4 hadis dari beberapa riwayat, yaitu: 1 dari riwayat tirmizi, 1 dari riwayat nasa’i, 1 dari riwayat ibnu majah, 1 hadis dari riawayat ahmad. Lihat mausu'ah hadis kutub al-Tis'ah berikut ini:

${ }^{44}$ Abdullah Malik ibn Anas ibn Malik ibn Abi Amir ibn Amr ibn al-Haris ibn Gaiman ibn Husail ibn Amr ibn al-Haris al-Asbahi al-Madani, Al-Mua'tha' Imam Malik (Beirut: Dar Fikri, t.th), hadis No. 1182 


\begin{tabular}{|c|c|c|c|c|}
\hline No & No Hadis & Perawi & Judul dalam Kitab Hadis & Teks Naskah Arab Kitab Hadis \\
\hline 1 & 1153 & Tirmidzi & $\begin{array}{l}\text { Dimakruhkan jual-beli apa yang } \\
\text { tidak ada padamu }\end{array}$ & ما جاء في كراهية بيع ما ليس عندك \\
\hline 2 & 4534 & Nasa'i & Menjual barang yang tak dimiliki & بيع ما \\
\hline 3 & 2178 & $\begin{array}{l}\text { Ibnu } \\
\text { Majah }\end{array}$ & $\begin{array}{l}\text { Larangan menjual sesuatu yang } \\
\text { bukan milikmu, dan dari mendapat } \\
\text { keuntungan dengan tanpa jaminan }\end{array}$ & النهي عن بيع ما ليس عندك وعن ربح ما لم يضمن \\
\hline 4 & 15021 & Ahmad & Hadits Hakim Hizam dari Nabi saw & مكيم بن حزام عن النبي صلى الله عليه وسلم \\
\hline
\end{tabular}

\section{Kesimpulan}

Hasil penelitian dapat disimpulkan bahwa dalam kitab mausu'ah al-hadis alNabawiyah, dari persepktif sembilan kitab hadis, yaitu bukhari, musim, abu daud, tirmizi, nasa'i, ibnu majah, ahmad, malik dan al-darimi, maka hadis yang berkaitan dengan kredit murabahah, penulis temukan ada dua hadis dari riwayat bukhari, satu dari riwayat tirmizi, empat dari riwayat nasa'i, tiga dari riawyat ahmad dan dua dari riwayat malik. Mausu'ah Bukhari ada dua hadis, yaitu Kitab : Jual beli, Bab: Nabi saw membeli dengan cara tempo, No. Hadis: 1926. Kitab : siasat mengelak, Bab: Hibah dan Syufah, No. Hadist: 6462. Mausu'ah Tirmizi ada satu hadis, yaitu Kitab : Jual beli, Bab: Larangan dua akad dalam satu jual-beli, No. Hadist: 1152. Mausu'ah Nasa'i ada empat hadis, yaitu Kitab : Iman dan nadzar, Bab: Perbedaan lafadh yang ma"tsur tentang Muzaro'ah, No. Hadist: 3875. Kitab: Jual-beli, Bab: Membeli perak dengan emas atau membeli emas dengan perak, No. Hadist: 4504. Kitab: Jualbeli, Bab: Menjual hewan dengan hewan yang dibayarkan secara tangguh, No. Hadist: 4541. Kitab: Jual-beli, Bab: Jual beli dengan ahli kitab, No. Hadist: 4571. Mausu'ah Ahmad ada tiga hadis, yaitu Kitab: Musnad sahabat yang banyak meriwayatkan hadits, Bab: Musnad Abdullah bin Mas'ud Radliyallahu ta'ala 'anhu, No. Hadist: 3595. Kitab: Musnad penduduk Madinah, Bab: Hadits Hisyam bin 'Amir Al Anshari Radliyallahu ta'ala 'anhu, No. Hadist: 15663. Kitab: Musnad penduduk Madinah, Bab: Hadits Hisyam bin 'Amir Al Anshari Radliyallahu ta'ala 'anhu, No. Hadist: 15675. Mausu'ah Malik ada dua hadis, yaitu Kitab: Jual-beli, Bab: Dari kakeknya, Malik bin Abu Amir, bahwa Utsman bin Affan. No. Hadist: 1148. Kitab: Jual-beli, Bab: Utang dan pengalihan utang, No. Hadist: 1182.

\section{Daftar Pustaka}

Abdullah Malik ibn Anas ibn Malik ibn Abi Amir ibn Amr ibn al-Haris ibn Gaiman ibn Husail ibn Amr ibn alHaris al-Asbahi al-Madani, (t.th), $A l$ Mua'tha' Imam Malik (Beirut: Dar Fikri)

Abdurrahman ibn 'Abdirahman ibn al-Fadhl ibn Bahram ibn 'Abdis Shamad, (t.th), Al-Sunan Al-Darimi (Kairo Mesir: Maktabah alamiyah) 
Abu 'Abdillah Muhammad bin Yazid bin 'Abdillah bin Majah al-Qazwini, (t.th), Al-Sunan Ibnu Majab (Mesir: Maktabah al-Sunnah)

Abu 'Abdirrahman ahmad bin su'aib bin ali bin bahr bin sinan bin dinar an-Nasai al-Kurasani, (t.th), Al-Sunan al-Nasa'i (Cairo: Dar Ilmi)

Abu 'Isa muhammad bin 'isa bin surrah alTurmudzi Ibn Musa Ibn AdhDhahak Al-Sulami Al-Bughi AlTirmidzi, (t.th), Al-Sunan Al-Tirmizi (Lebanon: Dar al-Hadis)

Abu Abdullah Muhammad bin Ismail AlBukhari bin Ibrahim bin Al-Mughirah bin Bardizbah, (t.th), Imam alBukhari, Sahih Bukhari (Bairut: Darul Ibnu Katsir al-Yammah)

Abu Zuhry dan Ahmad Sabiq, (2018), Hukum Jual Beli Kredit, lihat di wibesite online dalam https://abuzuhriy.wordpress.com/20 10/10/03/hukum-jual-belikredit/.diakses tanggal 21 september

Abul Husain Muslim bin al-Hajjaj alNaisaburi, Imam Muslim, (t.th), Shabih Muslim (Beirut: Dar Ibnu Katsir)

Ah. Azharuddin Lathif, (t.th), Konsep dan Aplikasi Akad Murababab Pada Perbankan Syariah di Indosesia..., (Buku Tidak Diterbitkan, Jakarta)

Ahmad bin Muhammad ibn Hanbal alSyaibany, (t.th), Al-Musnad Ibnu alHambali (Lebanon: Dar al-Hadis)

Ascarya, (2008), Akad dan Produk Bank Syariah, (PT RajaGrafindo persada, Jakarta)

Azzifathur Roifah, (2015), Implementasi Pembiayaan Murabahah Bil Wakalah Sebagai Upaya Untuk Meningkatkan Ekonomi, (Peternak Sapi Pada Lks
Asri Cabang Sendang Jurusan Perbankan Syariah Fakultas Ekonomi Dan Bisnis Islam Institut Agama Islam Negeri (IAIN) Tulungagung)

Budi Untung, (2004), Kredit Perbankan di Indonesia (Yogyakarta: Andi)

Bungin Burhan, (2004), Metodologi Penelitian Kualitatif, Jakarta: Raja Grafindo Persada.

Danupranata, Gita, (2013), Manajemen Perbankan Syariah (Jakarta : Salemba empat)

Dedy Mulyana, (2005), Metodologi Penelitian Kualitatif, Bandung: Remaja Rosdakarya

Hadari Nawawi, (2009), Metode Penelitian Bidang Sosial, Yogyakarta: Gajah Mada University Press

Hamidi, (2004), Metode penelitian kualitatif, Malang: Universitas Muhammadiyah Malang.

HB Sutopo, (2004), Pengantar Penelitian Kualitatif, Surakarta: Universitas Sebelas Maret Press.

Imam Suprayogo dan Tobroni, (2002), Metodologi Penelitian Sosial-Agama, Bandung: Remaja Rosdakarya.

Iskandar, (2010), Metode Penelitian Kualitatif : Aplikasi untuk Penelitian Pendidikan, Hukum, Ekonomi \& Manajemen, Sosial, Humaniora, Politik, Agama dan Filsafat, Jakarta: Gaung Persada

Kasmir, (2012), Bank dan Lembaga Keuangan Lainnya (Jakarta: Rajawali Pers)

Kasmir, (2013), Analisis Laporan Keuangan (Jakarta: Rajawali Pers), cet. VI, ed. 1

Khaerul Umam, (2013), Manajemen Perbankan Syariah (Bandung: CV. Pustaka Setia)

Kurneawati, (2011), Analisis Perlakuan Akuntansi Piutang Murabahah Pada PT. Bank BRI Syariab KCI Gubeng Surabaya, (Penelitian Tidak Diterbitkan, Surabaya) 
Lexy J Moleong, (2001), Metodologi Penelitian Kualitatif, Bandung: Remaja Rosdakarya.

Mahmud Yunus, (t.th), Tafsir Qur'an Karim, (PT. Hidakarya Agung, Jakarta)

Malayu Hasibuan, (2008), Dasar-Dasar Perbankan (Jakarta: PT Bumi Aksara)

Malayu Hasibuan, (2008), Dasar-Dasar Perbankan (Jakarta: PT. Bumi Aksara, 2008) dan (Jakarta: PT. Grafindo)

Miftah, (2018), Transaksi jual Beli Kredit (Cicilan) Dalam Syariat Islam, lihat wibesite online di http://mejamiftah.blogspot.com/2010/12/transa ksi-jual-beli-kredit-cicilan.html.diakses tanggal 20 september.

Muhammad Nazir, (1997), Metodologi Penelitian, Jakata: Ghalia Indonesia.

Muslim, (2018), Tinjauan Syariat Terhadap JualBeli Kredit, lihat di wibesite online https://muslim.or.id/20961-tinjauansyariat-terhadap-jual-beli-

kredit.html.diakses tanggal 20 september.

Neong Muhajir, (1998), Metodologi Penelitian Kualitatif, Yogyakarta: Rake Sarasin.

Nurhadi, (2016), Analisis Hukum Perikatan Klausul Akad Pembiayaan Murabahah Bil Wakalah Nomor.090/Mrbb/Pkb/V/2016 Bank Rakyat Indonesia Syariah (Tesis: Program Magister (S2) Program Pascasarjana Universitas Islam Riau Pekanbaru)

Nurhadi, (2017), Hilah Syariah Kredit Bank Konvesional (Maqashid Jual Beli Kredit (Lain Kontrak Lain Akad)), Jurnal Hukum Islam, Vol XVII No. 2 Desember

Nurhadi, (2017), Hilah Syariah Kredit Bank Konvesional (Maqashid Jual Beli Kredit
(Lain Kontrak Lain Akad)), (Jurnal Hukum Islam, Vol XVII No. 2 Desember)

Simorangkir, (2001), Pengantar Lembaga Keuangan Bank dan Non Bank (Jakarta: Ghalia Indonesia)

Sugiyono, (2006), Memahami Penelitian Kualitatif; Dilengkapi dengan Contoh Proposal dan Laporan Penelitian, Bandung: Alfabeta.

Sulaiman ibn al-Asy'ats ibn Ishaq ibn Bisyr ibn Syaddad ibn 'Amr ibn 'Imran, (t.th), Abu Dawud al-Azdi asSijistani, Shabih Sunan Abu Daud, (Lebanon: Dar al-Hadis)

Undang-Undang Nomor 21 Tahun 2008 tentang Perbankan Syariah Pasal 19 angka 1 huruf $\mathrm{d}$.

UU No 10 Th 1998 tentang Perbankan 